\title{
Pemahaman dan Implementasi Standar Pengelolaan Pendidikan di Madrasah Ibtidaiyah
}

\author{
Arsyad $^{1}$, Wahyu Bagja Sulfemi ${ }^{2}$, Ahmad Munthoi ${ }^{3}$ \\ ${ }^{2}$ STKIP Muhammadiyah Bogor, Indonesia \\ ${ }^{2}$ Institut Teknologi dan Bisnis Visi Nusantara, Bogor, Indonesia \\ ${ }^{3}$ SD Islam Al-Barkah, Jakarta, Indonesia \\ ${ }^{1}$ arsyaddjamaluddin@gmail.com \\ 2wahyubagja@gmail.com \\ ${ }^{3}$ kianmunthoi@gmail.com
}

\begin{abstract}
Abstrak:
Tujuan penelitian adalah untuk mengetahui tingkat pemahaman dan implementasi Standar Pengelolaan Pendidikan oleh Satuan Pendidikan Dasar dan Menengah, khususnya di Madrasah Ibtidaiyah. Metode penelitian menggunakan kualitatif deskriptif, dengan sumber data kepala madrasah, guru dan komite Madrasah Ibtidaiyah Kabupaten Bogor. Teknik sampling menggunakan profortional cluster random sampling, dengan metode pengumpulan data menggunakan kuisioner dan studi dokumentasi. Analisis data menggunakan statistik deskriptif. Hasil penelitian menunjukkan. Pertama tingkat pemahaman responden terhadap regulasi Standar Pengelolaan Pendidikan oleh Satuan Pendidikan Dasar dan Menengah, yaitu kepala madrasaha dan guru Madrasah Ibtidaiyah memiliki pemahaman yang cukup, sementara komite Madrasah Ibtidaiyah memiliki pemhaman dengan kaategori kurang paham. Kedua penilaian responden terhadap implementasi Standar Pengelolaan Pendidikan oleh Satuan Pendidikan Dasar dan Menengah di Madrasah Ibtidaiyah, yaitu kepala Madrasah, guru dan komite Madrasah Ibtidaiyah secara umu menganggap Madrasah Ibtidaiyah belum mengimplementasikan tata kelola sesuai Standar Pengelolaan Pendidikan oleh Satuan Pendidikan Dasar dan Menengah. Implikasi hasil penelitian ini bahwa dengan pemahaman responden yang secara umum hanya pada kategori cukup, maka berimplikasi pada implementasi tata kelola Madrasah Ibtidaiyah belum sepenuhnya mengacu pada standar pengelolaan pendidikan oleh Satuan Pendidikan Dasar dan Menengah. Hal ini menujukkan bahwa tingkat ketercapaian standar pengelolaan pendidikan di Madrasah Ibtidaiyah di klasifikasikan belum tercapai secara keseluruhan.
\end{abstract}

Kata kunci: Pemahaman; Pengelolaan; Implementasi; Tata Kelola; Madrasah Ibtidaiyah

\begin{abstract}
:
The purpose of the study was to determine the level of understanding and implementation of Education Management Standards by Primary and Secondary Education Units, especially in Madrasah Ibtidaiyah. The research method uses descriptive qualitative, with data sources
\end{abstract}


from the head of the madrasa, teachers, and the Madrasah Ibtidaiyah committee, Bogor Regency. The sampling technique used proportional cluster random sampling, with data collection methods using questionnaires and documentation studies. Data analysis used descriptive statistics. The results showed. First, the level of respondents' understanding of the regulation of Education Management Standards by the Primary and Secondary Education Units, namely the madrasah principal and Madrasah Ibtidaiyah teachers have sufficient understanding, while the Madrasah Ibtidaiyah committee has an understanding in the category of lack of understanding. The two respondents' assessments of the implementation of the Education Management Standards by the Primary and Secondary Education Units in Madrasah Ibtidaiyah, namely the head of Madrasah, teachers, and the Madrasah Ibtidaiyah committee generally considered that Madrasah Ibtidaiyah had not implemented governance according to the Education Management Standards by the Primary and Secondary Education Units. The implication of the results of this study is that the general understanding of respondents is only in the sufficient category, so the implementation of Madrasah Ibtidaiyah governance does not fully refer to the standards of education management by the Primary and Secondary Education Units. This shows that the level of achievement of educational management standards in Madrasah Ibtidaiyah is classified as not being achieved as a whole.

Keywords: Understanding; Management; Implementation; Governance; Madrasah Ibtidaiyah

\section{Pendahuluan}

Standar pengelolaan pendidikan diatur melalui Peraturan Menteri Pendidikan Nasional Republik Indonesia Nomor 19 Tahun 2007, tentang Standar Pengelolaan Pendidikan oleh Satuan Pendidikan Dasar dan Menengah, pasal 1 ayat 1, bahwa setiap satuan pendidikan wajib memenuhi standar pengelolaan pendidikan yang berlaku secara nasional. ${ }^{1}$ Salah satu standar yang diamanahkan dalam Peraturan Pemerintah tersebut adalah standar pengelolaan pendidikan. Pengelolaan pendidikan adalah kriteria yang akan dicapai secara efisien dan efektif yang didasarkan pada perencanaan program, pelaksanaan rencana kerja, pengawasan dan evaluasi, kepemimpinan sekolah/madrasah, serta sistem informasi manajemen. Standar pengelolaan pendidikan menjadi salah satu persoalan dalam pencapaian SNP. Rendahnya capaian standar pengelolaan pendidikan, khususnya di satuan pendidikan dasar juga dipengaruhi keterlibatan pemerintah daerah dalam pengelolaan pendidikan.

Buku Panduan MBS-SD menjelaskan bahwa, manajemen pengelolaan Sekolah/madrasah diartikan sebagai model pengelolaan yang memberikan otonomi (kewenangan dan tanggung jawab) lebih besar kepada sekolah/madrasah, memberikan fleksibilitas/keluwesan kepada sekolah/madrasah, dan mendorong partisipasi secara langsung

\footnotetext{
${ }^{1}$ Kementerian Pendidikan Nasional. Peraturan Menteri Pendidikan Nasional Republik Indonesia Nomor 19 Tahun 2007 tentang Standar Pengelolaan Pendidikan Oleh Satuan Pendidikan Dasar dan Menengah. Jakarta, Indonesia 2017.

260 | Ilmu Al-Qur'an (IQ) Jurnal Pendidikan Islam | Volume 04 No.2 2021
} 
warga sekolah/madrasah untuk meningkatkan mutu sekolah/madrasah berdasarkan kebijakan pendidikan nasional serta peraturan perundang-undangan yang berlaku².

Sebagai salah satu unit pelaksana pendidikan formal, madrasah dengan berbagai keragaman potensi peserta didik yang memerlukan layanan pendidikan yang beragam, kondisi lingkungan yang berbeda, maka madrasah harus dinamis dan kreatif dalam melaksanakan perannya untuk mengupayakan peningkatan mutu tata kelola madrasah. Persoalan klasik dari penyelenggaraan pendidikan di madrasah antara lain terkait dengan pengelolaan madrasah yang berada di bawah pembinaan dua kementerian yaitu Kementerian Pendidikan dan Kementerian Agama, kesenjangan antara madrasah negeri dan swasta, serta mutu madrasah yang masih rendah. ${ }^{3}$

Standar pengelolaan pendidikan di madrasah sebagai salah satu sub-sistem pendidikan nasional juga tidak terlepas dari permasalahan yang dihadapi oleh pendidikan nasional secara umum, termasuk peningkatan mutu tata kelola madrasah. Sebagai sebuah sistem pendidikan nasional, madrasah harus berpedoman pada SNP yang memuat delapan standar pendidikan, dan juga mengacu pada Peraturan Menteri Agama nomor 60 tahun 2015 tentang Penyelenggaraan Pendidikan, dalam pasal 1 disebutkan bahwa penyelenggaraan pendidikan Madrasah adalah kegiatan pelaksanaan komponen sistem pendidikan Raudhatufl Athfal, Madrasah Ibtidaiyah, Madrasah Tsanawaiyah, Madrasah Aliyah, dan Madrasah Aliyah kejuruan agar proses pendidikan dapat berlangsung sesuai dengan tujuan pendidikan nasional. ${ }^{4}$ Hal ini sejalan dengan Prioritas Renstra Kemenag tahun 2015-2019 adalah meningkatkan mutu Pendidikan Islam dengan beberapa isu strategis seperti pemenuhan hak terhadap pelayanan pendidikan dasar yang berkualitas, peningkatan kualitas pembelajaran (jaminan mutu, kurikulum dan sistem penilaian pendidikan), peningkatan manajemen guru, peningkatan efisiensi pembiayaan pendidikan dan peningkatan tata kelola pendidikan.

Pemerintah sebagai penanggungjawab pendidikan nasional berhak merumuskan kebijakan yang menjadi prioritas nasional terutama yang berkaitan dengan program peningkatan melek huruf dan angka, efisiensi, mutu, dan pemerataan pendidikan. Dalam hal ini sekolah/madrasah tidak diperbolehkan untuk berjalan sendiri dengan mengabaikan kebijakan dan standar yang ditetapkan oleh pemerintah. Manajemen sekolah/madrsah

\footnotetext{
2 Kementerian Pendidikan dan Kebudayaan Direktorat Jendral Pendidikan Dasar Direktorat Pembinaan Sekolah Dasar. Buku Panduan MBS-SD. PANDUAN PEMBINAAN Manajemen Berbasis Sekolah di Sekolah Dasar. Jakarta: Kementerian Pendidikan dan Kebudayaan, 2001

${ }^{3}$ Iskandar, Wahyu. Analisis Kebijakan Pendidikan Dalam Perspektif Madrasah. Madrasah:Jurnal Ilmiah Pendidikan Madrasah Ibtidaiyah. Vol. 4, No. 1, 2019. 1-21, tahun 2019.

4 Kementerian Agama RI. Peraturan Menteri Agama Nomor 60 Tahun 2015, tentang Penyelenggaraan Pendidikan Madrasah. Jakarta; Indonesia, 2015.
} 
menuntut dukungan tenaga kerja yang terampil dan berkualitas motivasi kerja yang lebih produktif dan memberdayakan otoritas daerah setempat, serta mengefisiensikan sistem dan menghilangkan birokrasi yang tumpang tindih. Melalui kinerja kepala sekolah/madrasah, guru dan keterlibatan masyarakat secara aktif dalam kaitannya dengan manajemen sekolah/madrasah adalah segala upaya yang dilakukan dan hasil yang dapat dicapai oleh pihak sekolah/madrasah dengan mengimplementasikan tata kelola sekolah/madrasah untuk mewujudkan tujuan pendidikan secara efektif dan efisien. Sehubungan dengan itu, maka tata kelola pendidikan di sekolah/madrasah harus; (1) kepemimpinan di sekolah/madrasah dijalankan sesuai tata kelola sekolah/madrasah secara efektif dan efisien, (2) memberdayakan guru-guru untuk melaksanakan proses pembelajaran dengan baik, dan (3) menjalin hubungan yang harmonis dengan masyarakat hingga dapat melibatkan mereka secara aktif dalam rangka mewujudkan tujuan sekolah dan pendidikan.

Berangkat dari hal tersebut, asumsi yang mendasari penelitian ini berangkat dari konsep bahwa pemahaman kepala madrasah, guru dan komite sekolah/madrasah terhadap standar pengelolaan pendidikan akan meningkatkan implementasi mutu pengelolaan pendidikan secara efisiensi dan efektif. Sebagai landasan kajian, maka penelitian ini merujuk pada beberapa hasil penelitian, antara lain: Pertama, hasil kajian tentang Upaya Meningkatkan Nilai Delapan Standar Nasional Pendidikan Akreditasi Sekolah melalui Supervisi Pembimbingan Terpadu pada Madrasah Ibtidaiyah di Kabupaten Sleman, dijelaskan bahwa pemahaman terhadap supervisi sebagai acuan normatif merupakan salah satu usaha yang di desain dengan fungsi; (1) mengarahkan, mengkoordinir, membimbing dan membina guru secara berkelanjutan (kontinu) baik secara individual ataupun kolektif dengan tujuan agar kinerja guru menjadi lebih baik, (2) memberi penilaian terhadap pengelolaan pendidikan di madrasah, dan (3) memecahkan berbagai masalah pendidikan secara efektif dan efisien ${ }^{5}$. Kedua, hasil penelitian yang menjelaskan tentang pemahaman dan implementasi standar pengelolaan pendidikan di Madrasah Ibtidaiyah harus dimulai dari sebuah proses transformasi, melalui peran dari kepala madrasah, guru dan komite madrasah yang akan mempengaruhi individu masing-masing personil untuk memahami dan mengimplementasikan tata kelola pendidikan, hal tersebut dikemukakan dalam penelitian tentang tingkat pemahaman kepala sekolah, guru, dan komite sekolah terhadap implementasi standar pengelolaan pendidikan pada satuan pendidikan dasar dan menengah, yaitu bahwa untuk mewujudkan manajemen tata kelola sekolah sesuai dengan

5 Wahyuni, Sri. Upaya Meningkatkan Nilai 8 Standar Nasional Pendidikan Akreditasi Sekolah melalui Supervisi Pembimbingan Terpadu pada Madrasah Ibtidaiyah di Kabupaten Sleman. Jurnal Pendidikan Madrasah, Volume 3, No. 1: 55-64.

262 | Ilmu Al-Qur'an (IQ) Jurnal Pendidikan Islam | Volume 04 No.2 2021 
standar pengelolaan pendidikan di satuan pendidikan dasar yang sejalan dengan tantangan revolusi industri 4.0 yang bertumpu pada cyber-physical system, sekolah dasar harus menghadirkan sumber daya manusia yang unggul, kompetitif, dan siap menghadapi era globalisasi ${ }^{6}$. Ketiga, hasil penelitian Tamam menyimpulkan bahwa ada 5 (lima) model pendidikan Islam untuk menyikapi kelima karakteristik era 4.0. yaitu; (1) model pendidikan eksistensialistik dalam rangka menyikapi perubahan tatatan kehidupan, (3) model pendidikan bercorak teknologi, (4) model pendidikan esensialistik dalam menyikapi tantangan agama, (5) model pendidikan profetik dalam menyikapi problem akhlak ${ }^{7}$.

Kajian tersebut dapat disimpulkan bahwa salah satu tantangan yang dihadapi pendidikan nasional termasuk pendidikan Islam (Madrasah) adalah penguatan manajemen kelembagaan dengan menekankan pada model pendidikan berbasis teknologi informasi sebagai bentuk peningkatan kapasitas dan penguatan kelembagaan yang berkesinambungan dalam pelayanan, manajemen dan tata kelola sesuai standar pengelolaan pendidikan. Untuk itu, dalam melaksanakan tata kelola manajemen kelembagaan pendidikan di sekolah/madrasah, maka kepala, guru, dan komite sekolah/madrasah dituntut untuk memiliki pengetahuan dan pemahaman yang baik terhadap manajemen pengelolaan pendidikan sesuai dengan peran dan tugasnya masing-masing. Adapun peran kepala madrasah, guru, dan komite sekolah/madrasah, yaitu sebagai berikut:

Pertama, peran kepala sekolah/madrasah dalam tata kelola pendidikan. Peran kepala sekolah/madrasah dalam menggerakkan kehidupan sekolah untuk mencapai tujuan dengan merujuk pada Peraturan Menteri Agama Nomor 58 tahun 2017, tentang Kepala Madrasah, Pasal 3 ayat (1) bahwa tugas kepala madrasah adalah; melaksanakan tugas manajerial, mengembangkan kewirausahaan dan melakukan supervisi kepada guru dan tenaga kependidikan ${ }^{8}$. Kepemimpinan di sekolah/madrasah adalah untuk memberdayakan guru, tenaga kependidikan dan masyarakat yang terlibat dengan memberikan kewenangan dalam mengambil keputusan sehingga mereka memiliki tanggung jawab yang besar. Sebagai pemimpin di sekolah/madrasah, kepala sekolah/madrasah dituntut untuk bertindak not us usual, but different and distinctive sekaligus secara berkelanjutan makin produktif, efektif,

6 Arsyad, Sulfemi, Wahyu Bagja, Yusfitriadi. Tingkat Pemahaman Kepala Sekolah, Guru, dan Komite Sekolah Terhadap Implementasi Standar Pengelolaan Pendidikan di Sekolah Dasar. Jurnal Pendidikan dan Kebudayaan, Vol. 6, Nomor 1, Juni 2021.

7 Tamam, Abas Mansur. 2020. "Model-Model Pendidikan Islam Dalam Merespons Era Revolusi Industri 4.0.” Jurnal PENAMAS Volume 33, No. 1: Januari-Juni. 2502-7891.

${ }^{8}$ Kementerian Agama RI. Peraturan Menteri Agama Nomor 58 tahun 2017 tentang Kepala Madrasah. Jakarta; Indonesia, 2017. 
efisien dan akuntabel ${ }^{9}$. Kepala sekolah/madrasah sebagai perencana dalam pelaksanaan tugasnya harus memahami tiga aspek yaitu; kondisi sekolah/madrasah yang ada (fact), kebijakan-kebijakan yang berlaku (policy), dan strategi implementasi yang efektif dan efisien $(\text { theory })^{10}$. Untuk itu, sebagai seorang pemimpin, kepala sekolah/madrasah haru mampu memandu, membimbing, membangunkan motivasi kerja, mengemudikan organisasi, menjalin jaringan komunikasi yang baik, memberikan supervisi atau pengawasan yang efisien dan membawa SDM yang ada untuk mencapai sasaran yang ingin dituju secara bersama-sama sesuai dengan ketentuan, waktu dan perencanaan.

Kedua, peran guru dalam tata kelola pendidikan di sekolah/madrasah. Guru sekolah/madrasah merupakan komponen yang berpengaruh dalam peningkatan mutu pendidikan di madrasah. Peran guru yang muncul secara intens selama ini dalam tata kelola sekolah/madrasah adalah sebagai pelaksana. Kebanyakan guru masih menganggap tugasnya adalah mengajar, setelah mengajar, mereka bebas dari tugas, sehingga berbagai hal yang terkait dengan tata kelola sekolah/madrasah ia lebih memilih menjadi pelaksana, karena ia menilai bahwa kewajibannya menjadi tanggungan pimpinan sekolah/madrasah ${ }^{11}$. Hal ini tidak salah, namun dalam perspektif yang lebih jauh, guru harus mampu menunjukkan bahwa apa yang dilakukan oleh semua warga sekolah harus mengarah pada satu tujuan bersama.

Peran guru dalam melaksanakan tata administrasi sekolah sangat penting, dan tidak bisa dipisahkan antara komponen yang satu dengan yang lain. Melihat tugas dan peran guru di sekolah/madrasah yang sebagai unsur yang berhadapan dengan peserta didik, maka guru yang bermutu merupakan faktor dan sangat menentukan bagi kemajuan dan kemakmuran suatu bangsa, sebab peningkatan kualitas guru merupakan faktor penting dalam mewujudkan SDM bangsa yang bermutu, yang siap dan mampu bersaing dalam pergaulan dan pasar kerja global saat ini. Dengan mengetahui dan memahami perannya sebagai bagian dari pelaksana tata kelola sekolah/madrasah, maka guru sekolah/madrasah dapat meningkatkan peranannya dalam melaksanakan tugas pokok pendidikan dan pengajaran, melaksanakan dan mengatur administrasi, pembinaan kesiswaan dan hubungan sekolah dengan masyarakat. Di samping itu,

\footnotetext{
${ }^{9}$ Sanusi, Achmad. Kepemimpinan Kependidikan. (Bandung; Nuansa Cendekia. 2013)

${ }^{10}$ Badarudin. Peran Kepala Sekolah Dasar dalam Mempersiapkan Sumber Daya Pendidik Menghadapi Implementasi Kurikulum 2013. Jurnal Dinamika Pendidikan Dasar, 10, No. 2: 2018: 74-84.

11 Sulfemi, W. Pengaruh Rasa Percaya Diri dan Gaya Kepemimpinan Kepala Sekolah Terhadap Kinerja Guru. Nidhomul Haq: Jurnal Manajemen Pendidikan Islam, 5, No. 2: 157-179. tahun 2020.
}

264 | Ilmu Al-Qur'an (IQ) Jurnal Pendidikan Islam | Volume 04 No.2 2021 
di sekolah/madrasah guru juga berperan sebagai perencana (planner), pelaksana dan penggerak (organizer), dan penilai (evaluator) terutama dalam pembelajaran ${ }^{12}$.

Peran guru yang muncul secara intens selama ini dalam pengelolaan sekolah/madrasah adalah sebagai pelaksana, kebanyakan guru masih menganggap tugasnya adalah mengajar, setelah mereka mengajar, mereka bebas dari tugas, sehingga berbagai hal yang terkait dengan tata kelola sekolah mereka lebih memilih menjadi pelaksana, karena ia menilai bahwa kewajibannya menjadi tanggungan pimpinan sekolah. Hal ini tidak salah, namun dalam perspektif yang lebih jauh, guru harus mampu menunjukkan bahwa apa yang dilakukan oleh semua warga sekolah harus mengarah pada satu tujuan bersama. Peran guru dalam melaksanakan tata administrasi sekolah sangat penting, dan tidak bisa dipisahkan antara komponen yang satu dengan yang lain. Melihat tugas dan peran guru di sekolah yang sebagai unsur yang berhadapan dengan peserta didik, maka guru yang bermutu merupakan faktor dan sangat menentukan bagi kemajuan dan kemakmuran suatu bangsa, sebab peningkatan kualitas guru merupakan faktor penting dalam mewujudkan SDM bangsa yang bermutu, yang siap dan mampu bersaing dalam pergaulan dan pasar kerja global saat ini.

Ketiga, peran komite dalam tata kelola pendidikan di sekolah/madrasah. Dalam mengimplementasikan hubungan sekolah dengan masyarakat, salah satu pendekatan yang digunakan adalah mengoptimalkan peran komite sekolah/madrasah yang dibentuk berdasarkan musyawarah oleh stakeholder pendidikan di tingkat sekolah/madrasah sebagai representasi dari berbagai unsur yang bertanggung jawab terhadap peningkatan kualitas proses dan hasil pendidikan. Hal ini mengacu pada Peraturan Menteri Pendidikan dan kebudayaan RI. nomor 75 tahun 2016 tentang Komite Sekolah, pasal 1 ayat (2) menyebutkan bahwa, Komite sekolah/madrasah adalah lembaga mandiri yang beranggotakan orang tua/wali peserta didik, komunitas sekolah, serta tokoh masyarakat yang peduli pendidikan ${ }^{13}$.

Hubungan madrasah dan masyarakat diharapkan mampu menumbuhkan kreativitas serta dinamika kedua belah pihak, sehingga hubungan tersebut bersifat aktif dan dinamis dan pada gilirannya prinsip transparansi yang dilakukan oleh keduanya akan mengarah pada profesionalisme pengelolaan kelembagaan yang akan membawa ke arah perubahan inovatif dan akan berdampak pada peningkatan mutu kelembagaan secara menyeluruh. Madrasah merupakan partnership dalam berbagai aktivitas yang berkaitan dengan aspek pengelolaan

12 Suyono dan Hariyanto. Belajar dan Pembelajaran Terori dan Konsep Dasar. (Bandung; Remaja Rosdakarya, 2013).

${ }^{13}$ Kementerian Pendidikan dan Kebudayaan. Peraturan Menteri Pendidikan dan Kebudayaan Republik Indonesia Nomor 75 Tahun 2016 tentang Komite Sekolah. Jakarta; Indonesia, 2016. 
pendidikan. Oleh karena itu, komite sekolah/madrasah harus memahami proses dan sistem pendidikan nasional agar dapat memberikan masukan sesuai dengan tuntutan dan perkembangan masyarakat, dengan menggunakan konsep manajemen strategis yaitu bersama dengan unsur sekolah/madrasah melakukan perencanaan strategi dan menentukan sasaran dalam mengambil keputusan.

Mencermati peran dan tugas kepala, guru dan komite sekolah/madrasah dalam implementasi pengelolaan pendidikan tersebut di atas dapat disimpulkan bahwa, kepala madrasah, guru dan komite madrasah memiliki peran penting dalam mengimplementasikan tata kelola sekolah yang sesuai standar pengelolaan pendidikan, karena itu, ia harus memahami dan mengetahui tentang: (1) Kondisi madrasah. (2) Kebijakan-kebijakan berlaku dan (3) Strategi implementasi yang efektif dan efisien. Dengan memahami tiga aspek tersebut, maka kepala madrasah, guru dan komite madrasah dianggap mampu mengimplementasikan tata kelola sekolah dengan mengacu pada indikator pada Standar Pengelolaan Pendidikan Oleh Satuan Pendidikan Dasar dan Menengah.

Banyak hal yang sudah dilakukan pemerintah, dalam hal ini Kementerian Agama agar penyelenggaraan pendidikan nasional terutama pada standar pengelolaan pendidikan dapat tercapai secara efisiensi dan efektivitas, mulai dari kebijakan yang bersifat teknis (regulasi) sampai pada upaya peningkatan sumber daya, termasuk memperkuat infrastruktur pendidikan. Namun dalam pelaksanaannya bahwa tingkat ketercapaian standar pengelolaan pendidikan terbilang masih rendah, sehingga perlu dilakukan evaluasi, dan juga mengingat bahwa implementasi standar pengelolaan pendidikan sudah berjalan kurang lebih 15 tahun, namun hasilnya belum optimal untuk mewujudkan pendidikan nasional yang bermutu.

Faktor yang dianggap paling mempengaruhi belum optimalnya aspek pengelolaan pendidikan khususnya pada satuan pendidikan dasar dan menengah adalah orientasi pengelolaan pendidikan selama ini yang lebih bersifat macro-oriented, yaitu pengelolaan pendidikan cenderung diatur oleh birokrasi ditingkat pusat institusi pendidikan dengan mengandalkan pola manajemen yang dianggap kurang efektif dan efisien dalam pelaksanaannya, sehingga hasilnya kurang maksimal, seperti pengelolaan pemberdayaan sumber daya, pengembangan program kerja sama madrasah, dan masih jarang memiliki dokumen rencana strategis (renstra) yang disusun sendiri bersama-sama stakeholder yang ada di lingkungan madrasah. ${ }^{14}$ Implikasinya banyak faktor yang diproyeksikan di tingkat micro

\footnotetext{
${ }^{14}$ Hadi, Saiful. Manajemen Mutu Madrasah Ibtidaiyah Berbasis Kearifan Lokal. Islamuna Volume 3 No. 2 : tahun 2016 .
} 
atau sekolah/madrasah tidak berjalan sebagaimana mestinya seperti faktor pemahaman warga sekolah/madrasah terhadap regulasi standar pengelolaan pendidikan yang belum utuh, antara lain karena mind set dari pengelolaan/madrasah yang belum tepat tentang apa itu tata kelola madrasah, bagaimana mengimplementasikannya, dan apa dampak yang terjadi apabila hal tersebut tidak berjalan dengan baik.

Untuk itu, evaluasi terhadap pengelolaan pendidikan oleh satuan pendidikan dasar dan menengah melalui evaluasi pada tingkat pemahaman pengelola di madrasah (kepala, guru dan komite) menjadi penting, karena tidak bisa dilepaskan dari peran masing-masing unsur dalam tata kelola madrasah sesuai dengan regulasi standar pengelolaan pendidikan. Ketercapaian standar pengelolaan pendidikan oleh satuan pendidikan dasar dan menengah dapat diukur dari sejauh mana kemampuan kepala sekolah/madrasah, guru dan komite madrasah dalam mengelola sumber daya dengan melakukan perencanaan program, pelaksanaan program, dan evaluasi program madrasah. Melalui manajemen tata kelola madrasah yang berjalan dengan baik dengan melibatkan kepala madrasah, guru dan komite madrasah, serta menjalin kerja sama yang harmonis antara sekolah, masyarakat dan pemerintah, maka diyakini dapat meningkatkan mutu tata kelola madrasah secara efisiensi dan efektif sesuai standar pengelolaan pendidikan. Untuk itu, kepala sekolah, guru dan komite madrasah dalam melaksanakan tugas tidak terlepas dari fungsinya dalam melakukan kegiatan manajemen yang terdiri dari perencanaan, pengorganisasian, evaluasi dan pengawasan sesuai dengan tugas dan kewenangannya masingmasing.

Berdasarkan urgensi penelitian, maka rumusan yang dibangun dalam penelitian ini adalah tingkat pemahaman dan implementasi pengelolaan pendidikan di Madrasah Ibtidaiyah yaitu bahwa faktor determinan yang mendorong pemahaman dan implementasi standar pengelolaan pendidikan di Madrasah Ibtidaiyah yang baik adalah di mulai dengan pemahaman yang tepat terhadap kebijakan regulasi pendidikan. Pengelolaan pendidikan di Madrasah Ibtidaiyah yang sesuai dengan kebijakan regulasi pendidikan yang ada dan terbangunnya kolaborasi dan kemitraan antara pelaku pendidikan dengan masyarakat, akan melahirkan implementasi pengelolaan pendidikan di Madrasah Ibtidaiyah yang sesuai dengan standar pengelolaan pendidikan.

Dari latar belakang dan kajian hasil penelitian di atas, maka kerangka konseptual penelitian ini adalah sebagai berikut; Pertama, bahwa pengelolaan pendidikan di Madrasah Ibtidaiyah tidak bisa dilepaskan dari tingkat pemahaman kepala sekolah/madrasah, guru dan komite sekolah/madrasah terhadap regulasi standar pengelolaan pendidikan sebagai panduan pengelolaan sekolah/madrasah. Regulasi standar pengelolaan pendidikan tersebut untuk 
memberikan pedoman dan petunjuk dalam pengelolaan pendidikan di Madrasah Ibtidaiyah yang sesuai standar nasional pendidikan. Dengan demikian, kebijakan regulasi standar pengelolaan pendidikan menjadi dasar dalam menjalankan program dan kegiatan pendidikan di Madrasah Ibtidaiyah. Oleh karena itu, kepala sekolah/madrasah, guru dan komite sekolah/madrasah dituntut untuk memahami dengan baik regulasi standar pengelolaan pendidikan, sehingga diharapkan akan berimplikasi pada pengelolaan pendidikan di sekolah/madrasah sesuai standar pengelolaan pendidikan di satuan pendidikan dasar menengah yang telah ditetapkan pemerintah. Kedua, kemampuan kepala sekolah/madrasah, guru dan komite sekolah/madrasah dalam mengimplementasikan standar pengelolaan pendidikan di sekolah/madrasah yang baik seperti memiliki kepemimpinan, kompetensi manajerial dan akuntabilitas, serta kemampuan menjalin kemitraan dengan masyarakat akan memberikan dampak pada pengelolaan sekolah/madrasah yang tepat sesuai standar pengelolaan pendidikan di Satuan Pendidikan Dasar Menengah yang telah ditetapkan pemerintah.

Berangkat dari hal tersebut, maka rumusan tujuan penelitian ini adalah; (1) untuk mengetahui tingkat pemahaman kepala madrasah, guru dan komite Madrasah Ibtidaiyah terhadap pengelolaan pendidikan sesuai standar pengelolaan pendidikan oleh satuan pendidikan dasar dan menengah; (2) untuk mengetahui sejuah mana implementasi pengelolaan pendidikan di Madrasah Ibtidaiyah sesuai standar pengelolaan pendidikan oleh satuan pendidikan dasar dan menengah.

Signifikansi penelitian ini sebagai hasil yang akan dicapai dengan kegunaan yaitu; (1) bagi kepala, guru dan komite Madrasah Ibtidaiyah akan mengetahui tentang pentingnya memahami regulasi pendidikan, terutama regulasi tentang standar pengelolaan pendidikan oleh satuan pendidikan dasar dan menengah; (2) bagi pemerintah, memberikan gambaran hasil penelitian tentang kendala dalam ketercapaian standar pengelolaan pendidikan di Madrasah Ibtidaiyah yang sesuai standar pengelolaan pendidikan oleh satuan pendidikan dasar dan menengah, sehingga diharapkan dapat mengambil kebijakan untuk melakukan evaluasi yang tepat, sistematis dan berkelanjutan dalam rangka menentukan strategi yang digunakan untuk mencapai SNP, khususnya pada ketercapaian standar pengelolaan pendidikan di Madrasah Ibtidaiyah.

\section{Metode Penelitian}

Penelitian pada dasarnya merupakan cara ilmiah untuk mendapatkan data dengan tujuan dan kegunaan tertentu. Kegiatan penelitian sebagai suatu cara dalam memperoleh pengetahuan atau memecahkan masalah yang dihadapi yang dilakukan secara ilmiah, 268 | IImu Al-Qur'an (IQJ Jurnal Pendidikan Islam | Volume U4 No.2'20'21 
sistematis dan logis dalam menempuh langkah-langkah tertentu ${ }^{15}$. Ada empat kata kunci yang perlu diperhatikan dalam penelitian yaitu; cara ilmiah, data, tujuan dan kegunaan. ${ }^{16}$ Penelitian ini menggunakan metode kualitatif dengan pendekatan deskriptif, lokus penelitian dilaksanakan di Kabupaten Bogor. Objek penelitian ini adalah seluruh Madrasah Ibtidaiyah Swasta di Kabupaten Bogor sebanyak 638 Madrasah Ibtidaiyah Swasta (MIS) yang tersebar di 40 Kecamatan di Kabupaten Bogor. Teknik sampling menggunakan profortional cluster random sampling, dengan langkah-langkah sebagai berikut; (1) menentukan wilayah secara klaster, yaitu dari 40 Kecamatan di Kabupaten Bogor diambil sebanyak 20\% wilayah, maka ditetapkan delapan kecamatan yang merepresentasikan empat wilayah Kabupaten Bogor yaitu; Bogor Tengah, Bogor Timur, Bogor Barat, dan Bogor Selatan; (2) menentukan jumlah Madrasah Ibtidaiyah Swasta (MIS) secara keseluruhan dari delapan kecamatan yang ditetapkan sebagai sampel wilayah, yaitu sebanyak 205 Madrasah Ibtidaiyah Swasta (MIS), kemudian ditetapkan 20\% sehingga diperoleh sebanyak 24 Madrasah Ibtidaiyah sebagai sampel dengan kriteria terakreditasi A, B atau C; (3) menentukan responden di setiap Madrasah Ibtidaiyah Swasta (MIS) yang dijadikan sampel, dengan unsur 1 kepala madrasah, 1 guru dan 1 komite Madrasah Ibtidaiyah, sehingga masing-masing Madrasah Ibtidaiyah tediri dari 3 responden, maka diperoleh jumlah sampel penelitian sebanyak 72 responden.

Data dalam penelitian ini terdiri dari data primer yaitu pemahaman dan penilaian kepala, guru dan komite Madrasah Ibtidaiyah terhadap tata kelola, sedangkan data sekunder adalah dokumen pelaksanaan kegiatan pengelolaan pendidikan Madrasah Ibtidaiyah di Kabupaten Bogor. Teknik pengambilan data menggunakan instrumen angket dengan skala likert. Analisis data menggunakan statistik deskriptif, yaitu menghimpun, menyusun, mengolah, menyajikan, dan menganalisis data agar dapat memberikan gambaran yang teratur, ringkas, dan jelas mengenai suatu gejala atau peristiwa. ${ }^{17}$ Analisis data dilakukan dengan mendeskripsikan tingkat pemahaman dan implementasi tata kelola Madrasah Ibtidaiyah sesuai dengan standar pengelolaan pendidikan menurut para responden.

15 Arsyad. Hubungan Antara Capaian Pembelajaran Dasar-Dasar Penelitian Dan Statistik dengan Mutu Skripsi: Studi Analisis di STKIP Muhammadiyah Bogor. KHAZANAH PENDIDIKAN. Jurnal Ilmiah Kependidikan, Volume XII, Nomor 2, Maret 2019.

${ }^{16}$ Sugiono. Metode Penelitian Kuantitatif Kualitatif dan R\&D. (Bandung; Alfabet. 2016).

17 Sudijono, Anas. Pengantar Statistik Pendidikan. (Jakarta; PT. RajaGrafindo, Persada 2012) 


\section{Hasil Penelitian dan Pembahasan}

Tingkat Pemahaman Kepala Madrasah, Guru dan Komite terhadap Standar Pengelolaan Pendidikan di Madrasah Ibtidaiyah.

Tujuan pertama pada penelitian ini adalah untuk mengetahui tingkat pemahaman responden terhadap standar pengelolaan pendidikan di Madrasah Ibtidaiyah sesuai standar pengelolaan pendidikan oleh Satuan Pendidikan Dasar Menengah. Hasil penelitian berdasarkan kelompok responden menunjukkan bahwa tingkat pemahaman responden dengan sebaran hasil angket berdasarkan indikator yaitu; kepala madrasah dan guru Madrasah Ibtidaiyah memiliki pemahaman rata-rata atau secara umum kategori cukup paham, sementara komite Madrasah Ibtidaiyah memiliki pemahaman dengan rata-rata kurang atau tidak paham. Berikut grafik hasil sebaran angket;

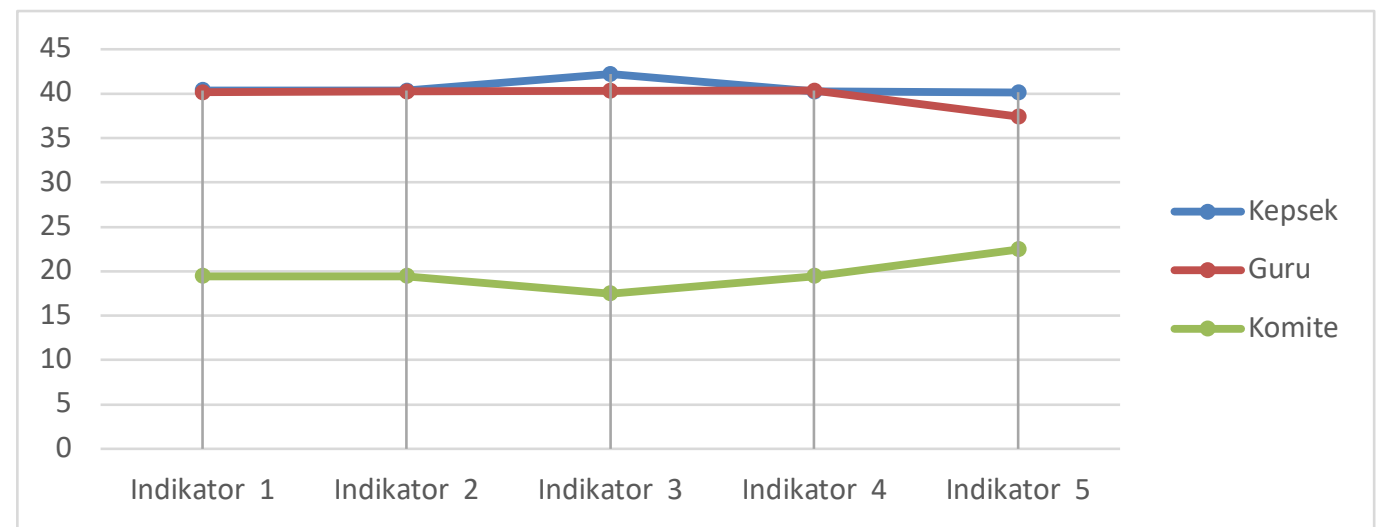

Grafi 1. Tingkat pemahaman responden terhadap pengelolaan MI

Berdasarkan grafik 1 hasil dari 5 butir angket pada masing-masing indikator tentang tingkat pemahaman responden terhadap tata kelola Madrasah Ibtidaiyah, dengan hasil sebaran sebagai berikut: Indikator pertama yaitu; perencanaan program, pelaksanaan rencana kerja dan kegiatan di Madrasah Ibtidaiyah, yaitu untuk kepala madrasah dengan nilai rata-rata sebesar $40,40 \%$, untuk guru dengan nilai rata-rata sebesar 40,15\% dikonversi menjadi keduanya masuk kategori cukup paham, sementara untuk komite dengan nilai rata-rata 19,45,38\%, dikonversi menjadi kategori sangat kurang paham. Indikator kedua yaitu; pengawasan dan evaluasi, data hasil penelitian menunjukkan bahwa responden kepala madrasah dengan nilai rata-rata 40,35\%, untuk guru dengan nilai rata-rata sebesar 40,22\% dikonversi keduanya masuka kategori cukup paham, sementara untuk komite nilai rata-rata 19,43\%, dikonversi menjadi kategori sangat kurang paham. Indikator ketiga yaitu; kepemimpinan di Madrasah Ibtidaiyah, data menunjukkan bahwa hasil untuk responden kepala madrasah dengan rata-rata $42,21 \%$, dikonversi menjadi kategori cukup paham, untuk guru nilai rata-rata 40,32\%, dikonversi menjadi kategori kurang paham, sementara komite memiliki nilai rata-rata 17,47\%, dikonversi 270 | Ilmu Al-Qur'an (IQ) Jurnal Pendidikan Islam | Volume 04 No.2 2021 
menjadi sangat kategori kurang paham. Indikator keempat yaitu; sistem informasi manajemen Madrasah Ibtidaiyah, berdasarkan data hasil sebaran butir angket menunjukkan tingkat pemahaman responden untuk kepala madrasah nilai rata-rata 40,24\% dikonversi menjadi kategori cukup paham, untuk guru dengan nilai rata-rata di atas $40,31 \%$, dikonversi menjadi kategori kurang paham, sementara untuk komite rata-rata nilai 19,45\%, dikonversi menjadi kategori sangat kurang paham. Indikator kelima yaitu; sekolah membangun kemitraan dan melibatkan peran serta komite Madrasah Ibtidaiyah, hasil sebaran 5 butir angket menunjukkan bahwa untuk kepala madrasah dengan nilai rata-rata 40,13\%, dikonversi menjadi kategori cukup paham, untuk guru dengan nilai rata-rata 37,42\% dikonversi menjadi kategori sangat kurang paham, sementara komite nilai rata-rata $22,45 \%$, dikonversi menjadi kategori sangat kurang paham.

\section{Implementasi Standar Pengelolaan Pendidikan di Madrasah Ibtidaiyah.}

Tujuan penelitian kedua adalah untuk mengetahui sejauhamana implementasi standar pengelolaan pendidikan di Madrasah Ibtidaiyah sesuai standar pengelolaan pendidikan oleh Satuan Pendidikan Dasar Menengah. Hasil penelitian berdasarkan kelompok responden menunjukkan bahwa penilaian responden terhadap implementasi tata kelola Madrasah Ibtidaiyah berdasarkan sebaran hasil angket dengan indikator yaitu; kepala madrasah dan guru memiliki penilaian rata-rata atau secara umum kategori kurang, sementara komite memiliki penilaian dengan rata-rata sangat kurang atau tidak paham. Berikut grafik hasil sebaran angket;

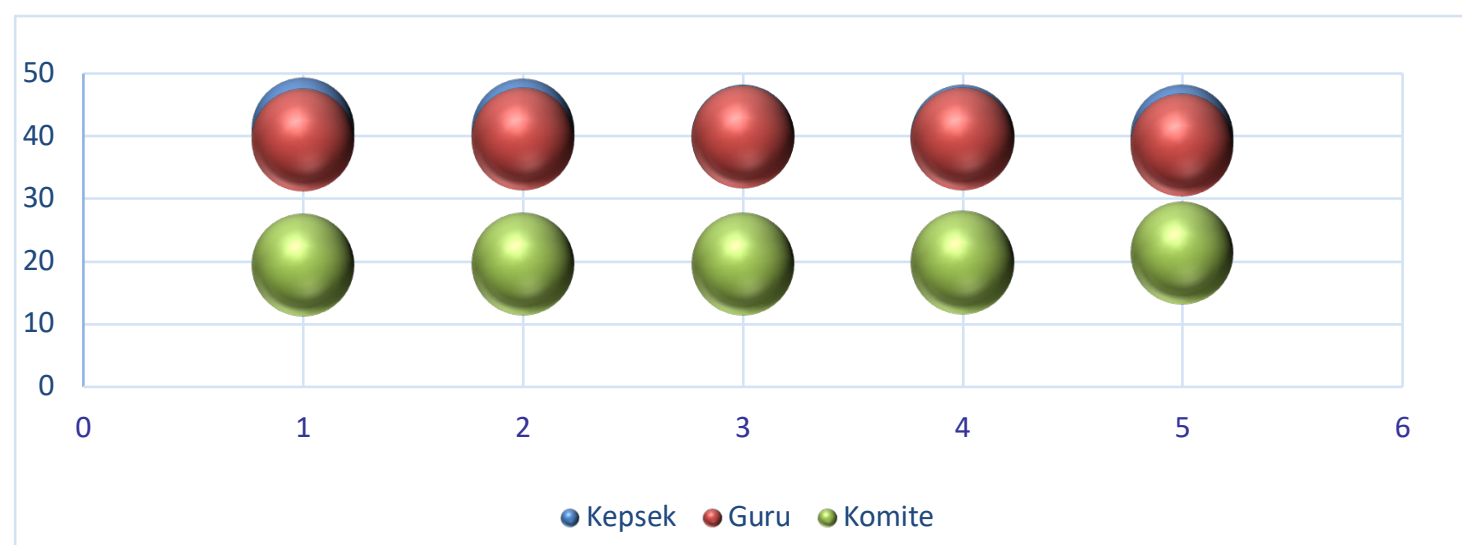

Grafik 2. Implementasi pengelolaan MI menurut responden

Berdasarkan grafik 2, pada tujuan kedua penelitian ini yaitu: Indikator pertama yaitu; perencanaan program, pelaksanaan rencana kerja dan kegiatan menunjukkan tingkat penilaian yang berbeda pada implementasi tata kelola pendidikan di Madrasah Ibtidaiyah sesuai standar pengelolaan, dengan hasil sebaran 5 butir angket menunjukkan untuk kepala madrasah memiliki penilaian rata-rata $41,25 \%$ dikonversi menjadi kategori cukup, untuk guru memiliki 
penilaian rata-rata 39,33\%, dikonversi menjadi kategori sangat kurang, sementara komite dengan penilaian rata-rata $19,42 \%$, dikonversi menjadi kategori sangat kurang. Indikator kedua; pengawasan dan evaluasi, untuk kepala madrasah penilaian rata-rata 40,90\%, dikonversi menjadi kategori cukup, untuk guru dengan menilai rata-rata 39,54\%, dikonversi menjadi kategori kurang, sementara komite dengan nilai rata-rata 19,56\%, dikonversi menjadi kategori sangat kurang. Indikator ketiga; kepemimpinan di Madrasah Ibtidaiyah, data hasil sebaran 5 butir angket menunjukkan bahwa kepala madrasah memiliki penilaian rata-rata $39,99 \%$, dikonversi menjadi kategori kurang, untuk guru dengan menilai rata-rata 39,89\%, dikonversi menjadi kategori kurang, dan menurut komite memiliki penilaian rata-rata 19,56\%, dikonversi menjadi kategori sangat kurang. Indikator keempat; sistem informasi manajemen, data menunjukkan bahwa kepala madrasah dengan penilaian rata-rata 39,99\%, dikonversi menjadi kategori kurang, dan guru dengan menilai rata-rata 39,56\%, dikonversi menjadi kategori kurang, sementara komite rata-rata penilaian 19,89\%, dikonversi menjadi kategori sangat kurang. Indikator Kelima yaitu; sekolah membangun kemitraan dan melibatkan peran serta komite Madrasah Ibtidaiyah, hasil penelitian menunjukkan bahwa kepala madrasah memiliki penilaian rata-rata 40,05\%, dikonversi menjadi kategori kurang, dan guru dengan menilai rata-rata 38,55\%, dikonversi menjadi kategori kurang, sementara menurut komite memiliki penilaian rata-rata $21,40 \%$, dikonversi menjadi kategori juga kurang.

Hasil penelitian pada tujuan penelitian pertama menjelaskan bahwa, tingkat pemahaman kepala, guru dan komite terhadap standar pengelolaan pendidikan di Madrasah Ibtidaiyah cukup bervariasi, namun secara umum tingkat pemahaman kepala sekolah dan guru ada pada kategori cukup paham, sementara untuk komite sekolah pada kategori kurang paham. Berdasarkan hasil sebaran butir angket per indikator, terlihat butir angket yang rata-rata cukup dipahami oleh responden yaitu; (1) kegiatan pengembangan kurikulum dan pembelajaran meliputi; kurikulum, kalender pendidikan, program pembelajaran, penilaian hasil belajar siswa dan peraturan akademik, (2) kegiatan perencanaan program, dan pelaksanaan rencana kerja, (3) dokumen presensi (daftar hadir) pendidik dan tenaga kependidikan, (4) pengelolaan keuangan dan pembiayaan pendidikan. Hasil tersebut menunjukkan bahwa pemahaman kepala madrasah dan guru Madrasah Ibtidaiyah pada beberapa aspek dalam indikator standar pengelolaan pendidikan di Madrasah Ibtidaiyah hanya pada kategori cukup paham. Salah satu penyebabnya adalah terbatasnya kesempatan guru dan tenaga kependidikan madrasah untuk 
mendapatkan pelatihan dalam jabatan (in-service training) yang berkelanjutan, bermutu dan terjangkau. ${ }^{18}$

Sementara hasil penelitian pada tujuan kedua, menjelaskan bahwa implementasi standar pengelolaan pendidikan di Madrasah Ibtidaiyah menurut penilaian kepala, guru dan komite Madrasah Ibtidaiyah secara umum dalam kategori kurang terimplementasi sesuai standar pengelolaan pendidikan. Hal ini terlihat pada hasil sebaran butir angket per indikator yang dianggap kurang terimplementasi menurut responden terlihat pada aspek seperti; (1) komite dan wali siswa belum memahami visi, isi dan tujuan, serta program-program Madrasah Ibtidaiyah, (2) tidak ada dokumen pelaksanaan kegiatan evalauasi kinerja pendidik dan tenaga kependidikan seperti; kesesuaian penugasan dengan keahlian, keseimbangan beban kerja, dan program supervisi di Madrasah Ibtidaiyah, (3) Madrasah Ibtidaiyah belum optimal dalam penggunaan sistem informasi manajemen (SIM)) dan tidak ada dokumen yang mendukung dalam pengelolaan, penyebarluasan dan penerimaan informasi berbasis online (website, blog, email, (4) komite Madrasah Ibtidaiyah belum terlibat secara aktif dalam mendukung kegiatan dan program Madrasah Ibtidaiyah, tidak ada dokumen kerjasama (MoU) antara Madrasah Ibtidaiyah dengan lembaga lain yang sudah ditandatangani yang dapat ditindaklanjuti, (5) kepala Madrasah Ibtidaiyah belum terlihat menumbuhkan jiwa kewirausahaan dan jiwa kepemimpinan yang kuat dengan keteladanan terhadap warga Madrasah Ibtidaiyah. Tidak lengkapnya beberapa dokumen kegiatan tata kelola pendidikan menunjukkan belum terimplementasinya standar pengelolaan pendidikan di Madrasah Ibtidaiyah sesuai standar pengelolaan pendidikan. Hal ini menjelaskan bahwa tingkat pemahaman responden pada standar pengelolaan pendidikan di Madrasah Ibtidaiyah juga rendah.

Berdasarkan data dan pembahasan hasil penelitian, bahwa tingkat pemahaman kepala madrasah dan guru terhadap standar pengelolaan pendidikan di Madrasah Ibtidaiyah yang hanya pada kategori cukup, memberikan gambaran bahwa implementasi tata kelola Madrasah Ibtidaiyah juga terbilang rendah, hal ini terlihat dari tidak lengkapnya beberapa dokumen tata kelola Madrasah Ibtidaiyah sebagai acuan dalam melaksanakan pengelolaan pendidikan yang sesuai standar pengelolaan pendidikan oleh satuan pendidikan dasar menengah. Rendahnya implementasi tata kelola sesuai standar pengelolaan pendidikan, kemungkinan disebabkan oleh kurangnya dukungan finansial dan rendahnya mutu input siswa, kurangnya fasilitas yang bermutu, dan kelemahan manajemen madrasah itu sendiri dalam hal pengelolaan. Melalui

\footnotetext{
18 Direktoray Jenderal Pendidikan Islam Kementerian Agama RI. Madrasah Reform 2020-2024. Realizing Education's Promise. (Jakarta; Madrasah Education Quality Reform, (IBRD 8992-ID).
} 
penguatan kelembagaan Madrasah Ibtidaiyah juga berimplikasi pada hasil pembelajaran yang tidak hanya dilihat dari ranah kognitif dan psikomotorik, tetapi juga dilihat dari hasil ranah afektif, yang akan melahirkan peserta didik yang taat dalam beribadah dengan karakter yang kuat sebagai seorang muslim yang taat pada Allah Swt. ${ }^{19} \mathrm{Ha}$ tersebut bisa terwujud apabila tata kelola kelembagaan Madrasah Ibtidaiyah juga terkelola dengan baik sesuai standar pengelolaan pendidikan oleh Satuan Pendidikan Dasar dan Menengah.

Hal tersebut disebabkan karena kepala madarasah, guru dan komite Madrasah Ibtidaiyah dalam melaksanakan tugas tidak terlepas dari fungsinya sebagai berikut: Pertama, peran kepala Madrasah Ibtidaiyah dalam tata kelola pendidikan. Peran kepala Madrasah Ibtidaiyah dalam menggerakkan kehidupan sekolah untuk mencapai tujuan dengan merujuk pada Peraturan Menteri Agama Nomor 58 tahun 2017, tentang Kepala Madrasah, Pasal 3 ayat (1) bahwa tugas kepala madrasah adalah; melaksanakan tugas manajerial, mengembangkan kewirausahaan dan melakukan supervisi kepada guru dan tenaga kependidikan. ${ }^{20} \mathrm{Kedua}$, peran guru dalam tata kelola pendidikan di Madrasah Ibtidaiyah. Guru berperan sebagai perencana (planner). Kepemimpinan (leadership) erupakan salah satu faktor yang menentukan pencapaian visi, misi, dan tujuan dari suatu lembaga atau organisasi. Kepala sekolah/madrasah, pengasuh pesantren, dekan, rektor, dan seluruh elemen pendidikan Islam. Kepala sekolah/madrasah sebangai pendidik (educator), kepala sekolah/madrasah sebagai manajer, kepala sekolah/madrasah sebagai administrator, kepala sekolah/madrasah sebagai supervisor, kepala sekolah/madrasah sebagai pemimpin (leader), kepala sekolah/madrasah sebagai pencipta iklim kerja, kepala sekolah/madrasah sebagai wirausahawan, dan kepala sekolah/madrasah sebagai inovator. ${ }^{21}$ Di madrasah guru juga berperan sebagai perencana (planner), pelaksana dan penggerak (organizer), dan penilai (evaluator) terutama dalam pembelajaran. ${ }^{22}$ Hasil penelitian Arsyad, menjelaskan bahwa pelaksanaan pembelajaran PAI oleh guru di sekolah/madrasah disebabkan salah satunya adalah faktor institusional, yaitu faktor latar belakang sosial ekonomi keluarga siswa, pengaruh teman sebaya, dan faktor media

19 Arsyad, Wahyu Bagja Sulfemi, Fajartriani. Penguatan Motivasi Shalat dan Karakter Peserta Didik melalui Pendekatan Pembelajaran Kontekstual Pada Mata Pelajaran Pendidikan Agama Islam. POTENSIA: Jurnal Kependidikan Islam, Vol. 6, No. 2: 185-204. Tahun 2020.

${ }^{20}$ Kementerian Agama RI. Peraturan Menteri Agama Nomor 58 tahun 2017 tentang Kepala Madrasah. Jakarta; Indonesia, 2017.

21 Nur Fauziah. Fungsi Leadership dalam Pengelolaan Lembaga Pendidikan Islam, Ilmu Al-Qur'an (IQ) Jurnal Pendidikan Islam Volume 3 No.02 (2020), 245-264.

22 Suyono dan Hariyanto. Belajar dan Pembelajaran Terori dan Konsep Dasar. (Bandung; Remaja Rosdakarya, 2013). 
dan lingkungan sekolah/madrasah. ${ }^{23}$ Ketiga, peran komite dalam tata kelola pendidikan di Madrasah Ibtidaiyah. Dalam mengimplementasikan hubungan sekolah dengan masyarakat, salah satu pendekatan yang digunakan adalah mengoptimalkan peran komite sekolah/madrasah yang dibentuk berdasarkan musyawarah oleh stakeholder pendidikan di tingkat sekolah/madrasah sebagai representasi dari berbagai unsur yang bertanggung jawab terhadap peningkatan kualitas proses dan hasil pendidikan. Hal ini mengacu pada Peraturan Menteri Pendidikan dan kebudayaan RI. nomor 75 tahun 2016 tentang Komite Sekolah, pasal 1 ayat (2) menyebutkan bahwa, Komite sekolah adalah lembaga mandiri yang beranggotakan orang tua/wali peserta didik, komunitas sekolah, serta tokoh masyarakat yang peduli pendidikan. ${ }^{24}$ Hubungan madrasah dan masyarakat diharapkan mampu menumbuhkan kreativitas serta dinamika kedua belah pihak.

Untuk itu, melalui manajemen tata kelola Madrasah Ibtidaiyah yang berjalan dengan baik yang melibatkan kepala, guru dan komite Madrasah Ibtidaiyah, serta menjalin kerja sama yang harmonis antara sekolah, masyarakat dan pemerintah, diyakini dapat meningkatkan mutu tata kelola Madrasah Ibtidaiyah secara efisiensi dan efektif sesuai standar pengelolaan pendidikan oleh Satuan Pendidikan Dasar Menengah. Mengacu pada kebijakan pemerintah tentang standar pengelolaan pendidikan untuk memenuhi ketercapaian SNP, maka kepala sekolah, guru, dan komite sekolah harus memiliki pemahaman yang baik terhadap regulasi standar pengelolaan pendidikan sehingga tata kelola sekolah berjalan sesuai dengan pedoman instrumen pengelolaan pendidikan di sekolah. ${ }^{25}$. Di samping itu, bahwa salah satu cara yang dapat dilakukan untuk meningkatkan mutu pendidikan adalah melalui manajemen berbasis sekolah, di mana dalam manajemen berbasis sekolah setiap satuan pendidikan diberikan kewenangan penuh untuk mengelola dan menyelenggarakan program pendidikannya yang melibatkan semua unsur. ${ }^{26}$

${ }^{23}$ Arsyad, dan Salahudin. Hubungan Kemampuan Membaca Al Qur'an dan Minat Belajar Siswa dengan Hasil Belajar Pendidikan Agama Islam (PAI). EDUKASI; Jurnal Penelitian Pendidikan Agama dan Keagamaan. 16 No. 2: 166-178, 2018.

${ }^{24}$ Kementerian Pendidikan dan Kebudayaan. Peraturan Menteri Pendidikan dan Kebudayaan Republik Indonesia Nomor 75 Tahun 2016 tentang Komite Sekolah. Jakarta; Indonesia, 2016.

${ }^{25}$ Arsyad Djamalludin Palettei, Wahyu Bagja Sulfemi, Yusfitriadi. Tingkat Pemahaman Kepala Sekolah, Guru, dan Komite Sekolah Terhadap Implementasi Standar Pengelolaan Pendidikan di Sekolah Dasar. Jurnal Pendidikan dan Kebudayaan, Vol. 6, Nomor 1, Juni 2021.

${ }^{26}$ Abu Maskur. Pengaruh Penerapan Manajemen Berbasis Sekolah Terhadap Mutu Pendidikan: Studi Kasus di SDITAl-Haraki Kota Depok. Ilmu Al-Qur'an (IQ) Jurnal Pendidikan Islam Volume 4 No.01 2021, 4350 . 
Dengan pemahaman yang baik terhadap regulasi standar pengelolaan pendidikan sehingga tata kelola sekolah berjalan sesuai dengan pedoman instrumen pengelolaan pendidikan di sekolah, maka dapat memperkuat kebijakan implementasi standar pengelolaan pendidikan di satuan pendidikan dasar, khususnya di Madrasah Ibtidaiyah melalui penguatan sumber daya manusia (SDM) yang unggul dan kompetitif agar dapat mendukung proses pendidikan ke depan dengan tantangan baru yakni pengelolaan kurikulum sesuai standar pendidikan era 4.0, konsep pembelajaran berbasis digital, serta guru profesional dan berkualitas. Dengan demikian, penguatan SDM Madrasah Ibtidaiyah diharapkan mampu menjawab tantangan dalam penyelenggaraan proses pendidikan sesuai standar pengelolaan pendidikan dengan manajemen modern berbasis sekolah dan berbasis jaringan internet. Oleh karena itu, semua unsur pendidikan harus berupaya untuk memenuhi standar pengelolaan pada tingkat pemerintah daerah dan satuan pendidikan dasar, termasuk guru dan masyarakat secara harus terlibat secara aktif dan proporsional sesuai dengan tugas dan tanggung jawabnya, serta bersama-sama dengan stake holder pendidikan dan pimpinan Madrasah Ibtidaiyah berkewajiban untuk mencapai standar Pengelolaan Pendidikan oleh Satuan Pendidkan Dasar Menengah, khususnya di Madrasah Ibtidaiyah.

\section{Kesimpulan}

Hasil penelitian ini menunjukkan, pertama, bahwa pemahaman responden terhadap standar Pengelolaan Pendidikan oleh Satuan Pendidkan Dasar yaitu; untuk kapala madarasah dan guru madrasah secara umum memiliki pemahaman dengan kategori cukup paham, sementara komite madrasah secara umum memiliki pemahaman dengan kategori kurang paham. Kedua, bahwa sejauh mana implementasi standar Pengelolaan Pendidikan oleh Satuan Pendidikan Dasar Menengah. Hasil menunjukkan bahwa penilaian responden terhadap implementasi tata kelola Madrasah Ibtidaiyah berdasarkan sebaran hasil indikator yaitu; kepala madrasah dan guru menilai Madrasah Ibtidaiyah secara umum belum mengimplementasikan standar Pengelolaan Pendidikan oleh Satuan Pendidikan Dasar Menengah dengan penilaian rata-rata kurang, sementara komite madrasah secara umum menganggap pihak Madrasah Ibtidaiyah belum mengimplementasikan standar Pengelolaan Pendidikan oleh Satuan Pendidikan Dasar Menengah dengan penilaian rata-rata sangat kurang paham.

\section{SARAN}

Mengacu pada hasil penelitian, maka saran yang disampaikan adalah; (1) bahwa sebagai bagian dari tugas pengelolaan, maka kepala madrasah, guru dan komite madrasah harus 276 | Ilmu Al-Qur'an (IQ) Jurnal Pendidikan Islam | Volume 04 No.2 2021 
memiliki pemahaman baik terhadap tata kelola pendidikan yang sesuai standar pengelolaan pendidikan oleh Satuan Pendidikan Dasar Menengah; (2) bahwa dalam mengimplementasikan tata kelola pendidikan, maka kepala madrasah, guru dan komite madrasah harus mengacu pada standar Pengelolaan Pendidikan oleh Satuan Pendidikan Dasar Menengah; (3 bahwa sebagai bagian dari salah satu pihak yang terlibat dalam pelaksanaan tata kelola pendidikan, maka pihak Madrasah Ibtidaiyah dituntut untuk memperkuat peran komite madrasah untuk mendukung program-program dan kegiatan Madrasah Ibtidaiyah sesuai dengan tugas dan fungsinya.

\section{Daftar Pustaka}

Abu Maskur. Pengaruh Penerapan Manajemen Berbasis Sekolah Terhadap Mutu Pendidikan: Studi Kasus di SDITAl-Haraki Kota Depok. Ilmu Al-Qur'an (IQ) Jurnal Pendidikan Islam Volume 4 No.01 2021, 43-50 (2020)

Arsyad, Arsyad, Sulfemi, Wahyu Bagja, Fajartriani Tia. Penguatan Motivasi Shalat dan Karakter Peserta Didik melalui Pendekatan Pembelajaran Kontekstual Pada Mata Pelajaran Pendidikan Agama Islam. POTENSIA: Jurnal Kependidikan Islam, Vol. 6, No. 2: 185-204. (2020)

Arsyad, Arsyad. Hubungan Antara Capaian Pembelajaran Dasar-Dasar Penelitian Dan Statistik dengan Mutu Skripsi: Studi Analisis di STKIP Muhammadiyah Bogor. KHAZANAH PENDIDIKAN. Jurnal Ilmiah Kependidikan, Volume XII, Nomor 2, Maret, 2019

Arsyad, Arsyad dan Salahudin. Hubungan Kemampuan Membaca Al Qur'an dan Minat Belajar Siswa dengan Hasil Belajar Pendidikan Agama Islam (PAI)". EDUKASI; Jurnal Penelitian Pendidikan Agama dan Keagamaan. 16 No. 2: 166-178. (2018)

Badarudin. Peran Kepala Sekolah Dasar dalam Mempersiapkan Sumber Daya Pendidik Menghadapi Implementasi Kurikulum 2013." Jurnal Dinamika Pendidikan Dasar, 10, No. 2: 2018: 74-84. (2018)

Hadi, Saiful. Manajemen Mutu Madrasah Ibtidaiyah Berbasis Kearifan Lokal. Islamuna Volume 3 No. 2: 2443-3535. (2016)

Iskandar, Wahyu. Analisis Kebijakan Pendidikan Dalam Perspektif Madrasah. Al-Madrasah: Jurnal Ilmiah Pendidikan Madrasah Ibtidaiyah. Vol. 4, No.1, 2019.1-21. (2019)

Kementerian Agama RI. Peraturan Menteri Agama Nomor 58 tahun 2017 tentang Kepala Madrasah. Jakarta; Indonesia.

Kementerian Pendidikan dan Kebudayaan. Peraturan Menteri Pendidikan dan Kebudayaan Republik Indonesia Nomor 75 Tahun 2016 tentang Komite Sekolah. Jakarta; Indonesia.

Kementerian Pendidikan Nasional. Peraturan Menteri Pendidikan Nasional Republik Indonesia Nomor 19 Tahun 2007 tentang Standar Pengelolaan Pendidikan Oleh Satuan Pendidikan Dasar dan Menengah. Jakarta; Indonesia. 
Arsyad Arsyad,Wahyu Bagja Sulfemi, Ahmad Munthoi

Kementerian Agama RI. Peraturan Menteri Agama Nomor 60 Tahun 2015, tentang Penyelenggaraan Pendidikan Madrasah. Jakarta; Indonesia.

Kementerian Pendidikan dan Kebudayaan Direktorat Jendral Pendidikan Dasar Direktorat Pembinaan Sekolah Dasar. Buku Panduan MBS-SD. PANDUAN PEMBINAAN. Manajemen Berbasis Sekolah di Sekolah Dasar. Jakarta: Kementerian Pendidikan dan Kebudayaan, Tahun 2001

Nur Fauziah. Fungsi Leadership dalam Pengelolaan Lembaga Pendidikan Islam. Ilmu AlQur'an (IQ) Jurnal Pendidikan Islam Volume 3 No.02, 245-264. (2020)

Palettei, Arsyad Djamalluddin, Sulfemi, Wahyu Bagja, Yusfitriadi. Tingkat Pemahaman Kepala Sekolah, Guru, dan Komite Sekolah Terhadap Implementasi Standar Pengelolaan Pendidikan di Sekolah Dasar. Jurnal Pendidikan dan Kebudayaan, Vol. 6, Nomor 1, Juni (2021)

Sanusi, Achmad. Kepemimpinan Kependidikan. Bandung; Nuansa Cendekia, 2013

Sudijono, Anas. Pengantar Statistik Pendidikan. Jakarta; PT. RajaGrafindo, Persada, 2012.

Sugiono. Metode Penelitian Kuantitatif Kualitatif dan R\&D. Bandung; Alfabet, 2016.

Suyono dan Hariyanto. Belajar dan Pembelajaran Terori dan Konsep Dasar. Bandung; Remaja Rosdakarya, 2013. 